\title{
The Role of Natural Resources for Sustaining Food Security in Ethiopia: A Review
}

\author{
Fayera Bakala \\ Mizan Tepi University \\ Milkessa Asfaw \\ Mizan Tepi University
}

\begin{abstract}
Natural resources can generate and sustain growth, thereby reducing poverty as well as maintain natural environment balance in addition to offering life supporting services for all organisms living on the planet. Well managed natural resources are expected to contribute to income and food security improvement in rural populations. However, food insecurity is the main obstacle to natural resource management in developing countries, especially in sub-Saharan Africa (SSA) and it is too challenging to achieve sustainable natural resource management and food security. Deteriorating soils and rapid extraction of natural resources is increasing in developing countries resulting in decreased food security. Thus, food insecurity remains high in most of SSA and natural resource management is marginalized, and gets less attention in development strategies. That insecurity is made even more serious due to degradation linked to escalated scarcity of natural resources. Natural resource management and food security is linked together. Developing countries, including sub-Saharan Africa, suffer from food insecurity. Sustainable use of natural resources means that the communities are enabled to plan and implement improvement measures which essentially (have to) take place at the community level. Such community based natural resource management will, however, only work and spread if it is accompanied and backed up by suitable political reforms at national and regional levels.
\end{abstract}

Keywords: Food security, natural resource, endowment, poverty trap, constraints

DOI: $10.7176 / F S Q M / 97-02$

Publication date:May $31^{\text {st }} 2020$

\section{Introduction}

Natural resources play a special role in the life of living beings. More than 1.3 billion people depend on fisheries, forests, and agriculture for employment or close to half of all jobs worldwide (FAO, 2004). According to the World Bank, in 2002, more than 90 percent of the 15 million people working on the world's waters were small-scale fishers, most of them poor, not including the tens of millions of poor who fish inland rivers, lakes, and even rice paddies for protein. About three in four poor people live in rural areas, where they depend on natural resources for their livelihoods, and about 90 percent of them depend on forests for at least some part of their income (USAID, 2006). In Africa, more than seven in ten poor people live in rural regions, with most engaged in resource-dependent activities such as small-scale farming, livestock production, fishing, hunting, artisanal mining, and logging. Poor people rely on related harvests as a primary source of income and fall back on natural resources when other sources of income fail.

Africa is endowed with substantial natural resources. It has enjoyed comparatively high rates of growth since the last decade, although in the world it remains the poorest region heavily reliant on natural resources. Natural resources, particularly land, soil, forests, water, animal and plant diversity, vegetation, related ecosystem services and renewable energy sources are crucial to attaining food security, enhancing livelihoods and realizing sustainable development in developing nations including Ethiopia (Sanginga et al., 2010). Africa is endowed with a very rich and diverse natural resource base on which the livelihood of its people, particularly the rural population, depends. However, the continent is still one of the most vulnerable with deepening levels of poverty and worrying trends of natural resources degradation (Campbell 2009).

A large number of individual's encounter challenges in obtaining reliable and sufficient access to food in developing nations. It has been predicted thatabout800 million people are chronically undernourished worldwide and lack enough to eat (OECD, 2000; FAO, 2014). Food insecurity is still one of the most noticeable manifestations of rural poverty and has drawn significant attention (Corbett, 1988; 1991, Abalu, 1999; Birara et al., 2015; FAO, 2014). Many African governments have vocally committed to taking measures aimed at ensuring sufficient food supplies for the populace at all times. Nevertheless, the precarious situation still exists (OECD, 2000).

Poverty eradication in Africa is largely dependent on the use of its natural resource base for the advantage of its people. Between poverty and natural resource degradation there is a strong correlation. Depletion and degradation of the natural resource base are taking place in different parts of the continent in order to alleviate poverty. This causes among other things unsustainable natural resource exploitation. It is difficult to achieve sustainable water resources management as a growing number of people still live in water-stressed environments 
in sub Saharan countries. Biodiversity continually declines due to growing pressures directly and indirectly (Scherr, 2000).

Realizing the dual goals of natural resource management and food security is amongst the key challenges presently staring at the emerging nations. Agricultural intensification uses various inputs to maximize food output to reduce/alleviate food insecurity. However, it is inimical to exposed natural resources like soils, forests, wetland areas and water resources. In a similar vein, a number of income diversification approaches greatly threatens natural resources. This review presents some arguments on natural resource management and food security and summarizes various dimensions of the literature that have been aimed at explaining options to realize sustainable food security whilst advocating wise management of natural resources.

\section{Natural Resource Management and Food Security Natural Resources}

A natural resource refers to air, forests, water, land, minerals, fisheries and wildlife delivered by nature (World Bank, 2001; Wiebe, 2000). Natural resources can either be renewable or non-renewable. The renewable ones are those capable of being replenished after having been used (e.g., water, wildlife, forests, etc) whereas the nonrenewable ones are those that, when exploited, are incapable of being regenerated (e.g., minerals and fossil fuels).Jointly, these resources create ecosystem services that underpin human welfare and existence (World Bank, 2001, Freeman, 2003). Natural resource degradation occurring in different parts of the world is especially serious in developing nations. This results from human induced activities in sub-Saharan Africa. But, in this case, as in other developing countries, the direct impact on human populations suffering under-nutrition and with little or no capacity to rehabilitate land is often much greater.

Over the past 50 years, the world's net cultivated area has grown by $12 \%$, mostly at the expense of forest, wetlands and grassland habitats. At the same time, the global irrigated area has doubled (FAO, 2011). Tropical forests were the primary source of new agricultural land in the 1980s and 1990s, representing about $30 \%$ of new agricultural land; $55 \%$ is represented by intact forest and $25 \%$ by disturbed forest (Gibbs et al., 2010). By 2050, the demand for new agricultural land (due to population pressure, diet change and demand for biofuel) is expected to increase by about $50 \%$. It is very probable that tropical forests will account for that land; therefore, further deforestation is to be expected, together with an exacerbation of soil degradation (Defries et al., 2010; Gibbs et al., 2010)

\section{Food Security}

Many definitions have been provided for food security. According to Clay (2002), food security is a situation that exits when all people at all times have physical, social and economic access to sufficient, safe and nutritious food that meets their dietary needs and food preferences for an active and healthy life. However, in this review paper, food security is defined as the adequate availability of and access to food for households to meet minimum energy requirements as recommended for active healthy life (Hussein and Janekarnkij, 2013). The minimum energy requirement for food security is $2,100 \mathrm{Kcal} /$ day (Devereux, 2006).

According to FAO (2014) the global population is expected to reach more than 9 billion by 2050. In the next 10 years, the population of sub-Saharan African cities is expected to increase by almost $45 \%$ and reach between 320 and 460 million. Much of this growth will be concentrated in low-income countries, which already face serious challenges in satisfying basic needs. The potential additional arable area for producing more food and animal feed is insufficient to meet future demand without producing more per hectare (GEF, 2016). Mark et al. (2013) indicated that population and income growth will drive food demand in the coming decades; nearly 80 percent more meat, 52 percent more cereals, and 40 percent more roots and tubers will need to be produced between 2005 and 2050 and the number of people at risk of hunger in the developing world would grow from 881 million in 2005 to more than 1,031 million people by 2050 .

Therefore, the world must start now to produce more food using available natural resources efficiently and sustainably, including a reduction of post-harvest losses and waste and developing a more resilient agriculture to climate change. If the world fails to achieve these projected food outputs for the future, people will be extremely exhausted potentially leading to extinction. Under current circumstances, the outlook for food supply and demand for the next decades poses many uncertainties about future global food security and the sustainability of natural resources (Regunaga and Marcelo, 2013).

Soil degradation has become a very serious problem in densely inhabited agricultural regions. India supports 18 percent of the world's human population and 15 percent of the world's livestock population, but has only 2.4 percent of the world's land area (Bhattacharyya et al., 2015). Soil degradation is causing a decline in crop productivity and huge economic loss, putting the food security and livelihood of farmers at risk (Bhattacharyya et al., 2015).In Sub-Saharan Africa (SSA), soil degradation (nutrient depletion is the primary form of soil degradation in SSA), is leading to a decline in crop productivity, and has been linked to hunger and poverty (Tully et al., 2015). 


\section{Linkages between Natural Resources management and Food Security}

The links between natural resource management and food security are vast. Environmental degradation may result in reduced productivity and food availability, while food insecurity may drive over-exploitation of limited resources as people resort to unsustainable practices to address immediate needs. This relationship is complex and calls for increased attention to identifying and addressing food insecurity in a timely manner, to help prevent unsustainable resource use (IFAD, 2014). In the context of climate change and economic crises, it is especially important to monitor food security as populations adapt to new conditions. Reliable and timely food security measurement is key both to understanding the links between natural resource management and people's access to food and to guide action (FAO, 2014).

Sustainable growth in agricultural production is vital for growth in food security. This is due to the fact that growth in agricultural productivity translates into increased food supplies and lower food prices for consumers as well as growth in agricultural productivity means higher incomes, and thus improved ability to purchase other basic necessities. This can be particularly essential for the numerous food insecure people who earn their livelihoods through agricultural production (Wiebe, 2001; Mark et al., 2013).

Changes in agricultural production over time can be attributed to variations in the quantity of resources used in agricultural production, like fertilizers, labor and land. Agricultural productivity is largely dependent on the quality of resources employed, including that of natural resources like land (Wiebe, 2001; Eric et al., 2015).According to Wiebe (2001) land (embodying soils, climate, and other characteristics) is one of the most basic resources used in agricultural production. Natural resources offer necessary life support services, in the form of both public and consumptive services, occasionally referred to as ecosystem services. Ecological processes help to maintain the cleansing of air and water, climate cycles, nutrient recycling, and soil productivity. Soils remain the foundation of agriculture, which is evidently the basic building block in the people's livelihood. Land alongside other resources interacts with food security through production, consumption as well as other processes (Figure 1). Better access to food thus enables improved investment in the improvement and protection of resources that help to create food security in the future (Wiebe, 2001).

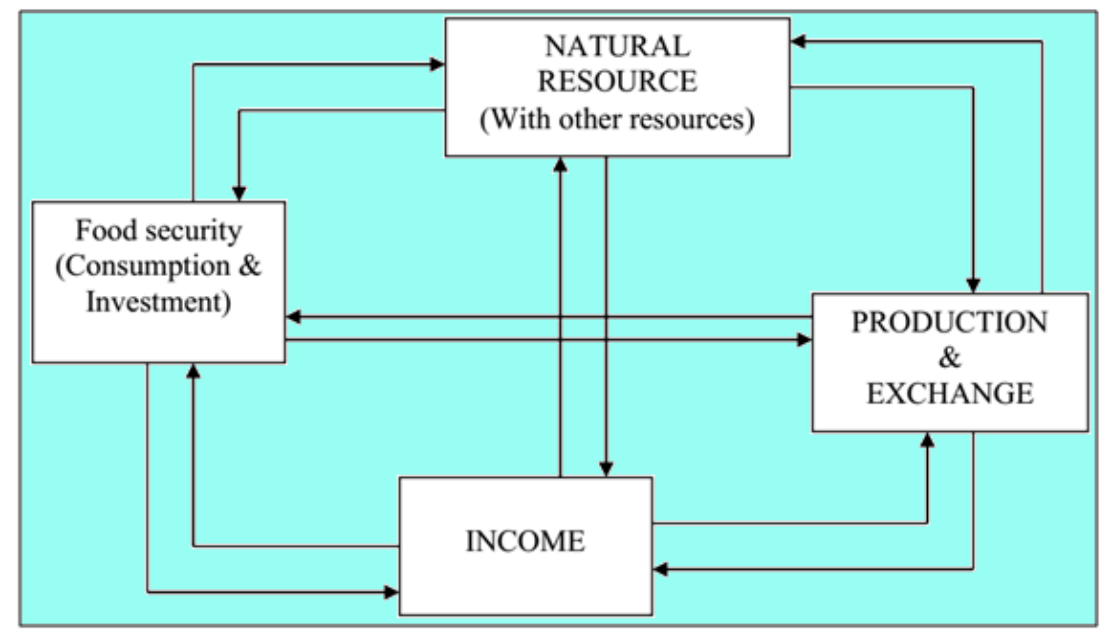

Figure 1: Food Security Linkages with Natural Resources (Source: Wiebe, 2001)

The condition of the world's natural resource base largely depends on whether poverty has been eradicated. Poverty and environmental degradation are closely linked, often in a self-perpetuating negative spiral in which poverty accelerates environmental degradation and degradation results in or exacerbates poverty-the so-called poverty trap (Figure 2) (Heltberg, 2001; Lee et al., 2001; World Bank, 2012). Poverty remains a noteworthy, persistent challenge in the evolving world. Based on this, to reverse the resource degradation trend in emerging countries demands due attention focused the eradication of poverty. 


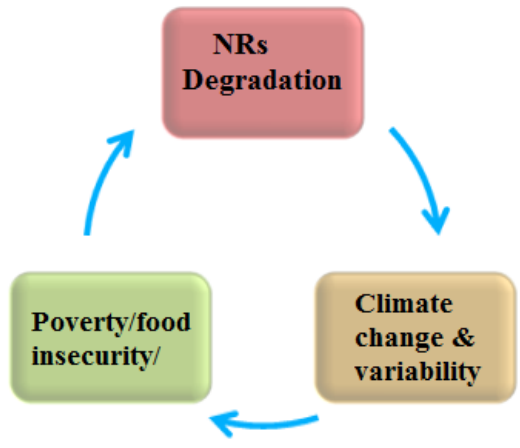

Figure 2: Poverty trap diagram (Source: Shiferaw et al., 2009)

Natural resources are crucial for nutrition and achieving food security. About 75 percent of protein consumption in Africa is derived from plant sources (UNEP et al., 2009). Fisheries, bush meat and livestock grazed in the wild provide much of the animal protein. For example, fish makes up 60 percent of the total animal protein consumed annually in hyper-arid Mali; and in Central Africa and West Africa Bush meat (wild animals and birds) is a major source of animal protein, making up more than 80 percent of consumption in some areas (UNEP et al., 2009). Additionally, during periods of stress such as drought, ill-health and economic change, food harvested from the wild play an important role. This indicates proper management and utilization of natural resource provides food and other services, which contributes to the food security and livelihood improvement of rural communities.

\section{Food Security Strategies and Their Impacts on Natural Resources Food Security Strategies}

A range of food security strategies has been adopted to enhance food self-sufficiency at the household level; among these Scones (1998) has identified three broad livelihood strategies: (i) Intensification, (ii) Extensificationo f existing productive activities and (iii) Diversification by adopting additional productive activities or migration to develop productive activities elsewhere.

In Western Africa, households gradually use their assets to responses to food shortages and food security emergencies (Milich, 1997; Shumete 2009). But when assets are exhausted, people with no alternative migrate to other areas. He further points out that the initial objective of coping options is to conserve household resources, and the ultimate objective may be the preservation of life. Agricultural expansion (extensification) into forests accounts for a larger proportion as a major strategy to increase agricultural production both for food and income for most of the people in developing countries especially in Sub-Saharan Africa (Cox head and Southgate, 2000; Sanchez et al., 2001; Bashaasha et al., 2001). Unplanned expansion of intensive production systems, which are typically monoculture and often developed at the expense of primary forests and savanna woodlands, can contribute to a significant loss in biodiversity. Much of the forest's trees covering the equatorial and tropical region in developing countries are being cleared so that an expansion of agricultural land uses is accommodated.

\section{Impacts of Food Security Strategies on Natural Resources}

Extensification/expansion is considered to be a major contributor to loss of habitat and reduction of biodiversity (Coxhead and Southgate, 2000; IRI, 2007; Fayera, 2017). This leads to a substantial release of greenhouse gases when forests are cut down. It has been estimated that agriculture accounts for about 30 percent of total $\mathrm{CO}_{2}$ emissions and greenhouse gases (Pagiola and Holden, 1999; Coxhead and Southgate, 2000; Dereje and Dev, 2008) and that this is due to deforestation and is the single most important source of these emissions. It is obvious that loss of forest cover due to extensive agricultural growth results in substantial downstream damage from sedimentation and change in the timing and volume of stream flows. Since extensification is taking place in increasingly fragile areas of the arid, semi-arid and dry sub-humid areas, it is leading to increased land degradation which results in the loss of biological and economic productivity well as accelerating expansion of deserts. Desertification leads to declining crop and livestock productivity, flora and fauna changes, climatic change and societal disruption in those areas. Households gradually use their own resources, and when the disaster strikes further, most of them migrate to other areas. This results in increased demand for marginal land, which has concomitant impacts on the resource base, eventually exacerbating land degradation. Eventually, land degradation becomes sufficiently severe as to result in continuation of a poverty trap because food insecurity begets environmental degradation, which begets further food insecurity (Godfray et al., 2010).

Practices for sustainable intensification of production - that will produce more on existing productive lands, while using fewer resources - will be increasingly necessary to meet demand for food and fibre (GEF, 2016). However, Adam and Gerald (2001) indicated that agricultural intensification often viewed as necessary for achieving increases in food output, but are potentially detrimental to vulnerable natural resources such as soils, 
forests, wetland areas and water resources. Moreover, Land use use does not necessarily lead to degradtion, not even insensitive land use. Proper short term investiments in inputs (fertilizer, seeds herbicides, fungicides, etc) and long term investment in equipments (pumps, tractors, dams, tareces, etc) can conserve soil and water, while allowing poductive and sustainable agricultural land use (Smil, 2000; Smil, 2003; Pimentel, 2008; Arizpe, 2011; Gomiero et al., 2011); however, framers in SSA cannot invest in these inputs and strucures regularly (Vries nad Molden, 2002). Thus, the only option for this region is to continue to degrade natural resources which slows down people's livelihood, unless off-farm employment provides an income without destroying the natural resource base.Expansion in land for production through deforestation and conversion of new land areas is occurring. According to Vries and Molden (2002) many consequences of degradation are local reduction in household food security and the threat of losing the capacity for achieving national food security, the high cost of restoring natural resources and the loss and devaluation for agricultural purposes and increased risks of natural disaster (land slide, drought flooding, as well as other issues).

\section{Natural Resources Management and Food security in Ethiopia}

The key characteristics of poverty in rural Ethiopia are: open natural resource access, dysfunctional community organizations, unplanned and uncontrolled settlement, destructive land uses and limited income opportunities. In many food insecure areas of Ethiopia this is exactly what has happened, and is continuing to happen. Despite huge natural resources of the country, rural communities become resigned to rely on external relief bodies, be they Government and/or NGOs. Even though women play a crucial role in natural resource management from family members, children and women bear the greatest pressures due to food insecurity in Ethiopia (Ethiopian Ministry of Foreign Affairs, 2010).For instance, the Bale zone of Oromia is known for its abundance of natural resources but these natural resources are now being degraded at an alarming rate, with consequent increases in livelihood vulnerability and food insecurity (PNRMU, 2008; Birara, 2015).

According to (MoFED, 2010) soil fertility depletion and erosion are threatening the sustainability of arable agriculture and there is an urgent need to rehabilitate damaged areas and prevent further deterioration through better soil fertility management, introduction of soil conservation measures, reforestation and appropriate conservation of agriculture methods. Rangeland degradation threatens the livelihoods of pastoral communities in large areas of the lowlands, calling for better rangeland management and alternative forms of income generation to reduce grazing pressure. Most of these initiatives aim to increase both productivity and sustainability and are therefore consistent with the other three strategic objectives.

Bale Forest Enterprise (BFE) and Bale Eco-Region Sustainable Management program(BERSMP) were aimed to stabilize and improve the food security situation of the Bale area based on the three pillar approaches: Community based Participatory Natural Resource Management; Community Enablement; and Sustainable Natural Resource based Livelihoods (Figure 3). In this case BFE and BERSMP made progress in rural livelihoods and natural resource conservation. Involving local people and their institutions in the management of natural resources has been identified as one of the most appropriate approaches to sustainable development. Thus, the program focuses on community level management of critical natural resources for poverty reduction.

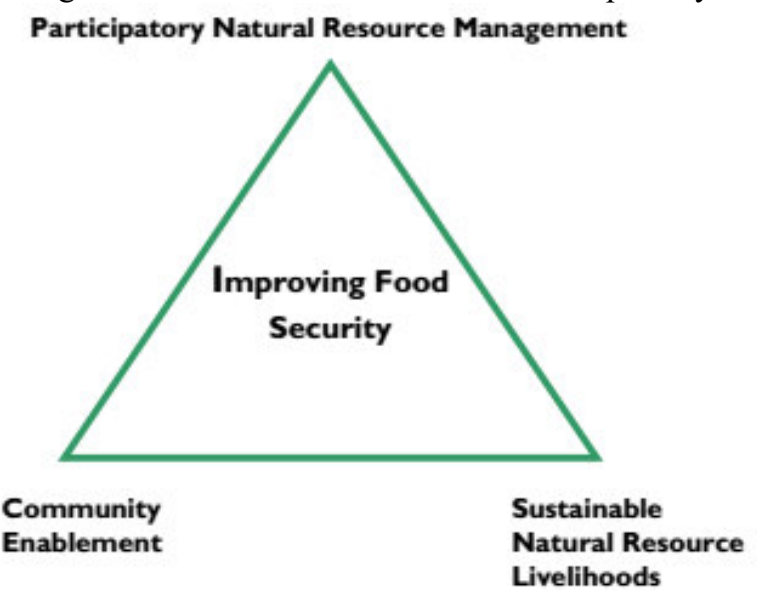

Figure 3: Participatory natural resource management food security (Source: PNRM, 2008)

Empowering local communities and indigenous people to become not only the primary stakeholders but also the primary caretakers and managers of natural resources should therefore be the ultimate goal of all future initiatives aimed at ensuring food security in which natural resource is an important component. This empowerment should aim at progressively devolving power and governance of natural resource management and utilization to the local communities. Moreover, integration of food security and climate change strategies have to be better integrated at every level. Adaptation to climate change also requires adequate means to promote 
management of natural resources. Community-based institutions are key to any community-based natural resource management (CBNRM) project and selecting and building the capacity of local institutions is critical. The selection process must ensure transparency and accountability and minimize conflict. Together with decentralization reforms, CBNRM ensures stakeholder participation, increases sustainability, and provides a forum for conflict resolution. Such a community-based approach often leads to more equitable and more sustainable natural resource management (Gruber, 2010).

\section{Natural Resource Endowment and Food Security}

The food security situation varies substantially between different regions/countries, depending on their resource endowments, production systems, economic development and culture, as well as on food consumption patterns associated with their growing per capita income. The challenge of achieving world food security and natural resources sustainability has a high priority. According to (Regunaga and Marcelo, 2013), food security and the sustainability of natural resources in developing countries rely not only on natural resources endowment, but also on a number of constraints influence utilization and management of natural resources, particularly in sub-Saharan Africa. These constraints include institutional, demographic, agro-ecological, technological and economic constraints (Adam and Gerald., 2001).

\section{Institutional Factors}

States in Africa have frequently undermined the capability of traditional institutions to manage natural resources by transferring authority to government agencies. Some of the institutional constraints that influence sustainable natural resource utilization and management include: inadequate property rights, lack and misappropriation of incentives, empowerment and inappropriate government policies (Nelson \& Agrawal, 2008).

\section{Demographic Constraints}

Population size as well as the rate of population growth influence resource management and use (UN-HABITAT, 2014); this directly affects the livelihoods of natural resource dependents. Population growth is a key catalyst of poverty-led environmental degradation. It has been widely reported in developing countries that population growth has led to the expansion of area under cultivation, accompanied by the conversion of large areas of natural resources and fragile land into agricultural production and settlements. Finally, this all exposes the people to food insecurity.

\section{Ecological Conditions}

Climatic variability is a key factor determining the inherent potential for decision-making of people particularly in sub-humid, semi-arid and arid areas in developing countries. The climatic conditions determine land use patterns in the area hence influencing natural resource utilization and management (Lee et al., 2001).

\section{Technological Constraints}

Inappropriate technologies for agricultural intensification in Africa also contribute to the failure of proper utilization and management of natural resources. Faulty agricultural practices, such as monoculture, and continuous cultivation of the same plot year after year leading to mining of nutrients from the soil, and contributing to soil degradation (Pinstrup et al., 1994).

\section{Economic Constraints}

In Africa, income is generated largely through domestic agricultural production, and a small proportion of income comes from non-farm activities. The only means to increase agricultural output in developing countries is through expansion of crop area under cultivation. This has contributed much to clearance of forest and expansion of agriculture into fragile land (Reardon, 1997).

\section{Conclusion}

Food security implies the provision of safe, nutritious, and quantitatively and qualitatively adequate food, as well as access to it by all people. Natural resources are resources provided by nature. These include forest, fisheries, wetlands, and grasslands among others. It is very challenging to maintain food security and natural resource use and management. Natural resources of Africa are important for nutrition and achieving food security; however, the lack sustainable management and utilization has paved the way to food insecurity. Poverty and natural resource degradation are closely linked. Poverty accelerates natural resource degradation and degradation results in or exacerbates poverty. Having high natural resources potential is not enough for food security without sustainable utilization and management as well as good governance of these resources as various factors influence or diverts these resources to fruitless things. These factors include: institutional constraints, technological constraints, demographic constraints, ecological constraints and economic constraints. Some strategies of food insecurity 
reduction and prevention mechanisms result in natural resource degradation. In order to achieve sustainable food security and natural resource management, it is mandatory to have clear participatory development strategies to balance natural resource management and food security in developing countries.

\section{References}

Abalu, G. I. (1999). Food security, rural economic linkages and the creation of employment in rural areas of Southern Africa. Agrekon, 38(S1), 20-45.

Arizpe, N.; Giampietro, M.; Ramos-Martin, J.(2003). Food security and fossil energy dependence: An international comparison of the use of fossil energy in agriculture . Crit. Rev. Plant Sci. 2011, 30, 45-63.

Bakala, F. (2016). Food insecurity in Ethiopia. city, 10, 0-2.

Bashaasha, B., Kraybill, D. S., Southgate, D. D., Barbier, E. B., \& Burgess, J. C. (2001). Land use impacts of agricultural intensification and fuelwood taxation in Uganda. Land Economics, 77(2), 241-249.

Bhattacharyya, R., Ghosh, B., Mishra, P., Mandal, B., Rao, C., Sarkar, D., \& Franzluebbers, A. (2015). Soil degradation in India: Challenges and potential solutions. Sustainability, 7(4), 3528-3570.

Campbell, B. (Ed.). (2009). Mining in Africa: regulation and development. IDRC.

Clay, E. (2002). Disasters, vulnerability and the global economy. Building safer cities: The future of disaster risk, 3 , $3-32$.

Comim, F., Kumar, P., \& Sirven, N. (2009). Poverty and environment links: an illustration from Africa. Journal of International Development: The Journal of the Development Studies Association, 21(3), 447-469.

Coxhead, I., \& Southgate, D. (2000). Economy-wide sources of agricultural expansion in developing countries.

Dereje, B \& Dev, S., (2008). Sustainable water harvesting and institutional strengthening in Amhara (WHISA). McGill on conference on Global food security. September 25-26

Devereux, S. (2006). Identification of methods and tools for emergency assessments to distinguish between chronic and transitory food insecurity, and to evaluate the effects of the various types and combinations of shocks on these different livelihood groups. Rome: United Nations World Food Programme.

Endalew, B., Muche, M., \& Tadesse, S. (2015). Assessment of food security situation in Ethiopia. World Journal of Dairy and Food Sciences, 10(1), 37-43.

Eric H., Justine W. and Caitlyn H., (2015). The World Bank Group's2013-15 Agriculture for Action Plan: A Lesson in Privatization, Lack of Oversight and Tired Development Paradigms. Development Report No 22.

FAO (The Food and Agriculture Organization of the United Nations) (2015). The State of the World's Land and Water Resources for Food and Agriculture (SOLAW)-Managing Systems at Risk; Food and Agriculture Organization of the United Nations: FAO, (2014). Nature \&Fauna: Sustainable Natural Resources Management in Africa's Urban Food and Nutrition Equation. Enhancing natural resources management for food security in Africa Volume 28, Issue 2.

Fayera Bakala (2017) Food Insecurity in Ethiopia: Food Science and Quality Management, Vol.52 .

Food and Agriculture Organization of the United Nations (FAO) (2004). The State of Food and Agriculture, Agricultural Biotechnology-Meeting the Needs of the Poor? Rome, Italy: FAO.

Freeman, R. B. (2003) \& Elliott, K. A., Can labor standards improve under globalization?. Peterson Institute Press: All Books.

Gibbs, H. K., Ruesch, A. S., Achard, F., Clayton, M. K., Holmgren, P., Ramankutty, N., \& Foley, J. A. (2010). Tropical forests were the primary sources of new agricultural land in the 1980s and 1990s. Proceedings of the National Academy of Sciences, 107(38), 16732-16737.

Global Environment Facility (GEF) (2016). Sustainable Land Management and its Relationship to Global EnvironmentalBenefits and Food Security - A Synthesis Report for the GEF. 50th GEF Council Meeting, Washington, D.C.

Godfray, H. C. J., Beddington, J. R., Crute, I. R., Haddad, L., Lawrence, D., Muir, J. F., ... \& Toulmin, C. (2010). Food security: the challenge of feeding 9 billion people. science,327(5967), 812-818.

Gomiero, T., Pimentel, D., \& Paoletti, M. G. (2011). Is there a need for a more sustainable agriculture?. Critical reviews in plant sciences, 30(1-2), 6-23.

Gruber, J. S. (2010). Key principles of community-based natural resource management: a synthesis and interpretation of identified effective approaches for managing the commons. Environmental management, 45(1), 52-66.

Hellmuth, M. E., Moorhead, A., Thomas, M. C., \& Williams, J. (2007). Climate risk management in Africa: Learning from practice.

Lee, D. R., Barrett, C. B., Hazell, P. and Southgate, D. 2001. "Assessing tradeoffs among agricultural intensification, economic development and environmental goals: Conclusions and implications for policy." In D. Lee and C. Barrett (eds) Tradeoffs or Synergies?Agricultural Intensification, Economic Development, and the Environment. CABI Publishing.

Mark Rosegrant, Jawoo Koo, Nicola Cenacchi, Claudia Ringler, Ricky Robertson, Myles Fisher,Cindy Cox, Karen 
Garrett, Nicostrato Perez, and Pascale Sabbagh (2013). Food Security in a World of GrowingNatural Resource Scarcity.The Role of Agricultural Technologies.

Masters, W. A., Djurfeldt, A. A., De Haan, C., Hazell, P., Jayne, T., Jirström, M., \& Reardon, T. (2013). Urbanization and farm size in Asia and Africa: Implications for food security and agricultural research. Global Food Security, 2(3), 156-165.

Milich, et al. (2014). KFCP Socio-economic Impact Study. Indonesia-Australia Forest Carbon Partnership.

Ministry of Agriculture and Rural Development (2010). Global Agriculture and Food Security Program Request for Funding Public Sector Window Agricultural Growth Program (GAFSP Gap Financing). Part1: Summary of Agriculture and Food Security Strategy and Post Compact Policy and Investment Framework Part 2: Country Proposal for GAFSP Funding.

MoFED, F. D. R. E. (2010). Growth and Transformation Plan 2010 (Vol. 15). 11-2014.

Mwakalobo, A., \& Shively, G. (2001). Food security and natural resource management in developing countries. Staff Paper, (1-12).

Nelson, F., \& Agrawal, A. (2008). Patronage or participation? Community-based natural resource management reform in sub-Saharan Africa. Development and change, 39(4), 557-585.

OCED (2000). Food security: No room for complacency. Highlight of the OECD information base. International future Programs.

Pagiola, S. and Holden, S. (2001). "Farm household intensification decisions and the environment." In D. Lee and C. Barrett (eds) Tradeoffs or Synergies? AgriculturalIntensification, Economic Development, and the Environment. CABI Publishing.

Pimentel, D.; Pimentel, M. (2008) Food, Energy, and Society, 3rd ed.; CRC Press: Boca Raton, FL, USA

Pinstrup-Andersen, P., \& Pandya-Lorch, R. (1994). Alleviating poverty, intensifying agriculture, and effectively managing natural resources (Vol. 1). Intl Food Policy Res Inst.

PNRMU, 2008. New Institutions and New Partnerships forParticipatory Natural Resource Management andFood Security. Policy Brief No.2.

Reardon, T. (1997). Using evidence of household income diversification to inform study of the rural nonfarm labor market in Africa. World development, 25(5), 735-747.

Regúnaga \& Marcelo. (2013). Seguridad alimentaria global y recursos naturales agrícolas. Ediciones De Yung.

Sanginga, P. C., Ochola, W. O., \& Bekalo, I. (2010). Natural resource management and development Nexus in Africa. Managing Natural Resources for Development in Africa: A Resource Book, 11.

Scherr, S. J. (2000). A downward spiral? Research evidence on the relationship between poverty and natural resource degradation. Food policy, 25(4), 479-498.

Scones, I. (1998). Sutainable rural livelihid: A framerk franalysis (Institute of Development Studies, Discussion Paper 295). Brightn, UK: University of Sussex.

Shiferaw, B. A., Okello, J., \& Reddy, R. V. (2009). Adoption and adaptation of natural resource management innovations in smallholder agriculture: reflections on key lessons and best practices. Environment, development and sustainability, 11(3), 601-619.

Shumete G., 2009. Poverty, Food insecurity and Livelihood strategies in Rural Gedeo: The case of Haroressa and Chichu PAs, SNNP; Proceedings of the 16th International Conference of Ethiopian Studies.

Smil, V. (2003). Energy at the Crossroads; The MIT Press: Cambridge, MA, USA.

Smil, V., (2000). Feeding the World: A Challenge for the Twenty-First Century; The MIT Press: Cambridge, MA, USA.

Tully, K., Sullivan, C., Weil, R., \& Sanchez, P. (2015). The state of soil degradation in Sub-Saharan Africa: Baselines, trajectories, and solutions. Sustainability, 7(6), 6523-6552.

UNEP (Lead Author); Mark McGinley, C Michael Hogan, (2009). "Biodiversity in Africa". In: Encyclopedia of Earth. Eds. Cutler J. Cleveland (Washington, D.C.: Environmental Information Coalition, National Council for Science and the Environment)

UN-HABITAT. (2014). The state of African cities: Re-imagining sustainable urban transitions. Regional State of the Cities Reports Series.

United States Agency for International Development (USAID) (2006). Issues in Poverty reduction and natural resource Management. Jeff brokaw usaid land resources Management team 1300 Pennsylvania avenue, NW Washington.

Vries, P., nad Molden, D. (2002). Sustaining food security and Managing Natural Resources in South East Asiachallenges for $21^{\text {st }}$ century, implications of land and water degradation for food security, with particular teference to Asia and Africa. International symmposim. January 8-11, 2002 at Chiang Mai, Thailand.

WB (2001). Making the IMF and the World Bank more accountable. International Affairs, 77(1), 83-100.

Wiebe, K. (2001). Natural resources, agricultural productivity and food security. Issues in food security. Economic Research Services United States Department of Agriculture. Agriculture information bulletin 765(3).

Woldeamanuel, S. G. (2009). Poverty, Food insecurity and Livelihood strategies in RuralGedeo: The case of 
Haroressa and Chichu PAs, SNNP. In Proceedings of the 16th International Conference of Ethiopian Studies, ed. by Svein Ege, Harald Aspen, Birhanu Teferra and Shiferaw Bekele, Trondheim.

World Bank (2002). The Environment and the Millennium Development Goals. Washington, DC: World Bank.

World Bank (2007). Poverty and the environment: understanding linkages at the household level. Environment and Development Series. Washington, DC.

World Bank (2012). Linking Gender, Environment, and Poverty for Sustainable Development: A Synthesis Report on Ethiopia and Ghana. Social Development Department Sustainable Development Network. Report no. P125713. 